\title{
Determining Industrial Change Effectiveness in Developing Countries: Focus on Ghana
}

\author{
Ernest Kwame Affum ${ }^{1}$ Haisu Wang ${ }^{2}$ \\ 1. School of Business Administration, Department of Industrial Economics, Zhongnan University of \\ Economics and Law, Hubei, China 430073 \\ 2. School of Business Administration, Department of Industrial Economics, and Centre for Intellectual \\ Property Valuation, Zhongnan University of Economics and Law, Hubei, China, 430073
}

\begin{abstract}
Ghana continues to grapple with the most appropriate approach to change the structure of the economy to ensure sustainable economic growth that will lead to social stability, closing up of the income inequality gap, alleviation of poverty, expansion of the economy and development of the industrial as well as agricultural and services sector. This requires pragmatic policy initiatives that are robust and address fundamental challenges facing industrial Ghana. This kind of policy must be driven by industry to avoid information asymmetry problem which can lead to defeat of such policy tools from the onset. This paper, (conceptual) using literature approach, has established EKs successful industrial change model as a means to influence industrial change activities and to analyze industrial change effectiveness in Ghana. It has proposed that, an effective industrial change, which is fundamentally rooted on policy changes, requires several dimensions to ensure its success. The proposed model asserts that government and industry are the main participants in such a task. However, there are social factors and SMEs development factors that can equally ensure an industrial change succeeds. Similarly, although government should mainly contribute to ensuring the industrial sector is able to drive industrial success which is the result of total factor productivity, socio-economic development and business expansion, government can equally contribute directly through SOEs and public-private partnerships (PPP). The paper therefore concludes that Government should collaborate with the industrial sector if this could be achieved.
\end{abstract}

Keywords: Industrial policy, industrial development, industrial change, developing countries, Ghana

DOI: $10.7176 / \mathrm{JESD} / 10-10-20$

Publication date:May $31^{\text {st }} 2019$

\section{Introduction}

Kwame Nkrumah (1965), the first president of Ghana, remarked: "Industry rather than agriculture is the means by which rapid improvement in Africa's living standards is possible." Industrialization and industrial activities have been an active part of governance in western democracies since the industrial revolution. Industrialization and industrial activities are driven by policies which are usually targeted at re-directing economic activities to ensure growth and development in an economy. Industrial organizations, as standard as they may be in advanced economies, have undergone many changes. These changes were necessitated by the need to make industrial organizations effective with the broader view of driving economic growth and social development. Thus, industrial organizations needed to be aligned with the aspirations of the government and the economy. This kind of alignment or re-alignment could be termed industrial change. Usually, an effective change in activities of industrial organizations requires a comprehensive list of activities. An industrial change would also mean a complete change in sectors of the economy aimed at sustainable development (OECD, 2014). For example, in their attempts to correct the anomaly witnessed in the economy, European governments directly took equity positions in domestic industries. Also, Italy's inspiration led Austria to pursue this form of industrial policy with utmost passion (Porter, Scully \& Slottje, 1986). Industrialization could be a complete undertaken or partial arrangement. Complete industrialization is undertaken as a total overhaul an (of) industrial sector of an economy. This is a very comprehensive task that requires much effort and funds to establish. Partial industrialization is a targeted program aimed at revitalizing and revamping sections of the industrial economy to facilitate economic change. The former is however difficult or almost impossible to achieve (See Leiper, Stear, Hing \& Firth, 2008; Backer \& Barry, 2012).

When Ghana attained independence from the British in 1957, the country was lighted with joy and excitement. Ghana was the first Sub-Saharan African country to gain political independence, in 1957. The new government led by Dr. Kwame Nkrumah in response to this new awe of enthusiasm and willingness to work for the country, initiated massive changes that could fast track the needed economic growth. This catching drive ushered in extensive structural changes led by massive industrialization program although this was not a complete departure from the Britain practice. Any in case, the total factor productivity was exported to Britain or some of its colonies. 
Notwithstanding, these changes were expected to fast-pace industrialization of the country. Also, this kind of industrialization drive was government-led, obviously because the government was socialist in ideology. The aim of the government at that time was to close the developmental gap that existed between Ghana and the West. The country enjoyed the highest per capita income in the sub-region and Ghana's economy was in an enviable position, with key indicators surpassing those of Malaysia, Hong Kong and some highly ranked economies today, compared to other British colonies (Friedrich Ebert Stiftung, 2004).

As earlier noted, Nkrumah and the Convention People's Party (CPP) instituted industry-wide reforms under a socialist ideology, including the dramatic seven-year plan spanning 1964 to 1970. Nkrumah sought pervasive industrialization through a Big Push strategy (catching up strategy), concentrating high rates of capital formation through domestic production of import-substitutes in state-owned enterprises. However, this plunged the country into increased public spending, culminating into huge public debt. The industrialization drive of Ghana although took off with such great momentum, was short-lived and the country started declining in its economic indicators. It led to huge buildup of public debt, which was the result of political instability, corruption, external shocks and the African-wide emancipation vision of Dr. Kwame Nkrumah, making him loose focus on Ghana's development path. The case in Ghana was not different from what was being practiced by other British colonies. Many chose an institutional framework that allowed for individual initiative, choice, and responsibility. Nationalism was on the rise and the independence movement witnessed after the World War II offered opportunities to many re-birthed countries to choose an acceptable institutional framework which had the capacity to drive progress. However, these initiatives did not mature to realize their full potentials for complete economic overhaul.

The military takeover did not help matters either. Ghana's economy continued in a downward trend until mid1980s when the Rawlings administration was forced to accept the Economic Reform Programme (ERP) under Structural Adjustment Programme (SAP) with trade liberalization being one of the main tenets of this IMF led initiative. Although investor confidence was raised as a result of the upward turn of economic indicators prompted by the SAP, this began to grow worse during the early 1990s. Other economic policies such as the Ghana Poverty Reduction Strategy (GPRS) I and II ensued. The point been made here is that, all these economic policies and programs were intended to enforce a change in the industrial structure of the country. In 2010, the government of Ghana initiated yet another industrial policy framework. This was intended to facilitate the achievement of the long term strategic goals of the country. The main aim of the policy was the attainment of a middle income status by 2020. It was intended to drive the industrial policy development of the government. Also, it was aligned to the trade policy of the country, which also conformed to the development agenda of the country.

In sum, Ghana has embarked on numerous policy changes and measures with the aim of making significant changes in the Ghanaian industry so as to promote growth and foster development in the country. However this measures have not been fruitful in helping the country to achieve and succeed with regards to mechanisms that could make significant changes in the Ghanaian economy and this is perhaps due to the fact that Ghana relies heavily on Foreign Direct Investment (FDI) for significant changes in the industrial sector and a lot of attention is paid to foreign investment campaigns at the highest levels of government. This has brought serious problems of dumping of cheap and inferior goods on the country, thus, stifling industrial organizations, siphoning natural resources meant to fuel industrialization of the country and increasing poverty levels due to unemployment.

This research thus seeks to ascertain factors necessary for industrial change effectiveness in Ghana to enable the country achieve its socio-economic, as well as political targets. This will enable the researcher to make appropriate recommendations on mechanisms for effective policy design, execution, and monitoring that can be adopted by Ghana in order to make significant and successful changes in its industrial drive as well as highlight other measures needed to ensure industrial change success. It will also investigate how these measures could be sustained over the long term since sustainability is an important factor to consider when developing a mechanism for successful industrial changes. In other words, this research will be conducted to provide solid foundation for effective industrial change. Invariably, this research will first, provide essentials tools for effective policy formulation and implementation; second, link policy changes to industrial successes and policy success assessment using selected indicators, and also to contribute to the literature on industrial development in Ghana and invariably, developing economies.

\section{Methodology}

This study will follow the interpretivist research paradigm that implies that the study will primarily use qualitative approach. The reason for this, as argued by numerous scholars, is that the qualitative approach is perhaps the most appropriate research method for explanatory and descriptive studies Since this study seeks to suggest a mechanism 
for analyzing and assessing the success of industrial change in Ghana, it best suits the study (Babbie, 2004). The adoption of this research approach enabled the researcher to first begin the study with a philosophical assumption on some of the measures that have been taken by Ghana over the years to effect changes in Ghanaian industries which to a large extent have not achieved the intended result, thus, serve as the basis for this research since the main task of the research is to offer innovative ways by which Ghana could achieve successful and sustainable change in its industrialization drive so as to foster growth and development at large. Also this approach gave the opportunity for the researcher to bring on board new perspectives with regards to the issue under discussion as well as create platform for the use of interpretive, theoretical frameworks and effective model to further shape the study so as to arrive at a logical and unbiased conclusion. Furthermore, qualitative approach as argued by other scholars is to offer the opportunity to dwell on the works of other experts who have conducted some works on the topic under discussion (Patton, 2005) and in fact adopting this approach enabled the researchers to review literature as well as the works of renowned institutions and scholars that have focused their studies on discussing possible mechanisms for industrial change in developing economies. This eventually aided the researchers in obtaining a rich and in-depth insight into the research problem under discussion. The materials used for the research were predominantly secondary sources of information such as documents from the internet, journal articles, reports, policy documents as well as all other important reading materials such as the dailies, press releases, news items and official reports. With regards to the innovation and contribution of this research to existing literature, the research made use of a combination of various theories and models such as Adam's Smith invisible hand theory and Hagel's theory of government intervention to establish and innovative mechanism for successful policy change in the Ghana's industrial sector.

\section{Literature Review}

Industrial organization studies have focused much attention on monopoly and how governments can redirect market activities to reduce monopoly power. This among others is directed at making policy relevant and to promote easy access to industrial concentration data (Demsetz, 1973). In a world in which information and resource mobility can be secured only at a cost, an industry will become more concentrated under competitive conditions only if a differential advantage in expanding output develops in some firms. The cost advantage that gives rise to increased concentration may be reflected in scale economies or in downward shifts in positively sloped marginal cost curves, or it may be reflected in better products which satisfy demand at a lower cost. New efficiencies can arise in other ways (Demsetz, 1973). Some firms might discover ways of lowering cost that require that firms become smaller, so that spinoffs might be in order.

Marxist's political economy theory seeks to explain the institutional aspects of media and telecommunication systems, with reference to the historical relationships between owners, labor, consumers, advertisers, and the state. New growth theories suggest that differences in growth rates may result from increasing returns to knowledge. One source of increasing returns may be agglomerations or geographic concentrations of knowledge that provide a means to facilitate information searches, to increase search intensity and to ease task co-ordination in general (Feldman et al., 1999). Knowledge is not easily contained and for this reason, location yield higher rates of economic growth. Despite the fact that the debate between these opposing views has not yet been resolved (Glaeser, 2000), recent interventions in literature found evidence that the influence of Jacobs' externalities on innovation increases together with technological intensity, while the Marshall-Arrow-Romer externalities are important for innovation in mature industries (Henderson et al., 1995; Greunz, 2004). In recent years the concept of innovation as a driver of economic growth has shifted away from that of being an individualistic 'linear' technology transfer process, towards an incremental, endogenous, group activity. What then is the means by which the industrial sector can change its current functional activities to make enterprises in the industry relevant in the economic growth activities of the country?

The resource-based view as propounded by Robert Grant presents a paradigm shift in economic thought and firm development from industry characteristics and competitiveness to firm resources in an attempt to achieve sustainable competitive advantage (Spanos and Lioukas, 2001) since its inception in the mid-1980s (Wernerfelt, 1984; Rumelt1984; Barney, 1986). Resources comprise production inputs in the form of capital equipment, employees' knowledge and skills, intellectual properties, etc. In terms of industrial change effectiveness, firms are required to develop their capabilities in order to ensure industry is moving towards contributing to economic growth. This cannot be left to government alone as governments' role is to initiate policy and program changes, but enterprises are the real drivers of industrial development. However in extreme case of market failure, government (as in the case of establishment of SOEs) can establish strategic enterprises to meet needs of consumers. 
Industrial organizations have been much taunted to facilitate the rate of economic growth other than the agriculture or service economy. Some scholars have argued that in order to sustainably develop local industries, it is important to critically examine some assessment indices and also some important factors such as geographical environments, cultural history, development processes, and industrial policies and the commitment of governments to promote industrial change while at the same time trying to achieve sustainable industrial development should also be taken into consideration (Pan and Chiu, 2017). In the view of these scholars, not only should the government formulate policies aimed at making changes in local industries but it is important for the government to ensure that such changes are sustainable over the long term and can stand the test of time. These scholars adopted the fuzzy Delphi method to construct the indices for assessing development in the local industry. The study concluded that certain important factors such as infrastructure of a country, deep and critical innovative research and development as well as government policies are crucial elements that contribute to development of the local industry in developing countries.

According to some researchers, (Liau and Chou, 2000; Fan and Chou, 2008; Barberia and Biderman, 2010), local industries can develop not only through government policies and initiatives but more importantly local industrials should make use of and explore external factors to their advantage in their developmental process. The external factors listed by scholars include but are not limited to improvement of regional economies, flexibility in national land control, regional job opportunities, improvement in professional services and association between cultural activities, as well as the rate of regional consumption. In a nut shell, these scholars argue that the development of local industries does not only rest on mechanisms that are instituted by the government of a given country. However, local industries also have a crucial role to play in order to actualize the dream of achieving effective change in their developmental process. Thus, the local industries need to also research and explore external factors like creating association of among themselves in a regional block in order to share ideas, train and improve their professional service.

From another perspective, factors such as technological development or advance, scientific innovation, and the establishment of learning networks resulting from clustering are perhaps the most important factors that need to be given attention if a country intends to achieve continual development of its local industries. This view is supported by Yu, Lu and Luo (2010) and Chen, (2007). A study on the lotus industry in Baihe District proved that industries that have distinctive local features are categorized by regional concentration, geopolitical interactions, and minor industrial scales can be simply supported and developed by means of effective and efficient industry design (Yu, Lu \& Luo, 2010; Chen, 2007) and deliberated on the current progress of local industries with distinguishing local features and the trend of local industrial development and concluded that for local industries to develop, they need to first of all think beyond the local market and expand their market to the international arena, improve their product with respect to innovation and modification to reflect the changing circumstance of the world, develop talents with the aim of rendering support for industries with unique local features, and strengthen the harmony that exist between the government and private businesses.

Other studies also argued that the mechanism for the development of local industries can be divided into external and internal factors. In the view of Huang (1998), plans to make policies or design a mechanism for industrial change, both external and internal factors to the industry must be taken into consideration. In other words, the macro aspects which are made up of factors such as the external environments, industrial structures, public facilities, as well as social responsibility are critical and should not be ignored. Additionally, the micro aspects which on the other hand include factors such as production and distribution capacity, revenue mobilization, strength, and other benefits of the industry must be given a critical consideration when engaging in industrial planning. Researchers, such as Coelli et al. (1998), argued that in order to determine and ensure that local industries are functioning well to expectation, policy makers should take into consideration basic internal conditions and external factors. They noted that internal basic conditions that are crucial and needs to be considered include land price, industrial structure, public facilities and the services they provide, the laws and regulations governing the protection of the environment and local capital markets. Examples of external factors are the global economy, macroeconomic rules and regulations, monetary and fiscal policies, and energy and transportation regulations. Also $\mathrm{Yu}, \mathrm{Lu}$ and Luo (2010), agrees with this line of argument and points out two factors namely the pull factor, which are found within the industry and the push factor, which mainly emerges from the government as the important factors that need to be considered when making plans for industrial change.

An industrial change success in Africa is impeded by three main factors - policy failures, externalities and structural variables. Low level human capital, poor and deficit infrastructure, small market size, and over dependence on public jobs, as well as imports (Lall, 2004a) are key structural factors that undermine effectiveness of industrial change. Other factors that contribute to industrial change in developing countries are (1) lack of 
national plan and strategy and the problem of definition of industrial policy on partisan political lines (Nnana, 2000). The inability of governments to direct capital, labor and intermediate inputs (energy, materials and services) into more productive areas or sectors of the economy is another major setback in industrial policy design and success (Tsu-tan Fu et al., 2014).

\subsection{Determinants of Industrial Change Success}

The structure of a market, which shows how a market is functioning, "is the concept behind the industrial organization theory" (Tirole, 1988, p. 1). Thus, Ramsey (2001, p. 39), was of the view that industrial organizational theory should focus on market activities other than firm operations. This can be demonstrated in the structureconduct-performance (S-C-P) model that emphasizes direct effect of market structure as a domain within which enterprises function, the firm's conduct and the implication on performance measured by organizational profitability (Ramsey, 2001, p. 39). Since industrial change is closely linked to activities of industrial organizations, it is imperative to emphasize the role of the S-C-P model in ensuring effective industrial change. This is also situated within the context of the original proposition made by economist, Afred Marshall that firms are situated around competition and there are interactions that occur between the firms and the competition (Corley, 1990, p. 84). The inclusion of the role of the entrepreneur to adapt to the changing circumstances as means of appraising the value of the firm due to information asymmetry was necessary (Corley, 1990, p. 85). In the view of Barthwal (2004, p. 68), market structure comprises the (1) degree of seller concentration, (2) degree of buyer concentration, (3) degree of product differentiation and (4) conditions for entry. Seller concentration tends to promote monopoly which determines the strategy that can be adopted by the market due to loss of competition (Mohamed, Shamsudin, Latif \& Mu'azu, 2013, p. 1457; Bain, 1968). Buyer concentration can also determine the buying behavior of the market. With a few number and size distribution, buyer can possess higher negotiating power (Bain, 1968, p. 150). Product differentiation can be determined through cross-elasticity of demand due to change in the price of a product. Low differentiation implies higher prices thereby leading to decrease in sales and vice versa (Bain, 1968, p. 224225). Barriers to entry are factors that present the entry of new firms to the market, which could be the use of specific device, product differentiation and volume requirement (Shepherd \& Wilcox, 1979, p. 40).

Market conduct describes the activities of the market in terms of how resources are used to achieve enterprise goals. These are undertaken through investments, advertising, pricing, and research and development. These actions could be independently undertaken or there could be collusion with other competitors on issues such as innovation, product strategies and advertising (Tung et al., 2010, p. 1119). Advertising as a conduct (Carlton \& Perloff, 2000, p. 4) of the firm focuses on information dissemination to consumer in respect of product "existence, quality, price and terms of sales" (Ferguson \& Ferguson, 1994, p. 62) to aid consumers in their decision making. The pricing behavior of the market could be explained from different facets. First, mutual interdependence can lead to monopoly when companies collude to fix prices. In an oligopoly situation, it is unlikely for such an activity since all firms have almost the same selling price and production cost structure (Bain, 1968, p. 119). To achieve higher than normal profits whiles lowering output however, there must be strong collusion among firms (Ferguson \& Ferguson, 1994, p. 17; Evanoff \& Fortier, 1988, p. 278). Firms have used mergers and acquisitions and contracting to gain market power. In the view of Shepherd \& Wilcox (1979, p. 164-165), horizontal merger is a market power tool when two firms in the same market merge through acquisition or stock offering to increase profit and gain a larger market share. Technical economics and pecuniary economics are other forms of direct market power (Shepherd \& Wilcox, 1979, p. 164-168). Generally, research and development (R\&D) lead to new or improved processes and technology, new or improved products and services, quality, method of production, development and improvement of new market, and new supplier base (Ferguson \& Ferguson, 1994, p. 111 In: Schumpeter, 1934, p. 66).

The SCP model shows that company performance is the result of market structure and conduct. The performance of the market therefore can be measured in ways such as "production efficiency, advance technology, product quality and profit rate" (Tung et al., 2010, p. 1119). In industrial organizations however, the performance is measured by economic welfare, which implies satisfying the needs of consumers whiles making efficient use of resources. Since basic conditions that determine industry operations were added to the S-C-P model Carlton \& Perloff (2000, p. 4) described them as consumer demand and production condition. Also, factors of firm and basic conditions comprise psychological, technological, geographical and institutional elements.

An industry is characterized by the type of technology, products and services, production and manufacturing processes, type of market (demand and supply sides), location and relatedness, cluster and association, type of equipment marketing and marketing capabilities [23]. Policies should not only be driven by research or market, 
but a combination of both will ensure industrial policies are effective to tackle the changes expected in industry. The action of government to interfere in market operations due to distortions may not necessarily lead to public or economic welfare (Ferguson \& Ferguson, 1994, p. 6). This might be as a result of lack of information which is usually controlled by industry. In Ghana however, policies are neither research driven nor market driven. Policies are driven by political or social sentiments which in most cases do not have real economic and industrial basis. This increases the level of information asymmetry since most of the information needed for industrial policy to be effective is held and controlled by the market. Additionally, the input of scientific research would ensure policies have both theoretical and practical basis, but this medium is often ignored by government in its policy design and implementation approach. In general, this is described as the "informational and rent-seeking constraints". When this happens, as argued by Rodrik (2008), policy follows the "principal-agent" paradigm. Government should therefore liaise with relevant institutions in this regard.

Industrial change success could also be the result of effective organizational change, Victor and Franckeiss (2002) postulated a cyclical process that outlines five principles necessary for an effective change as (1) need for flexiblestructured approach, (2) need for consistent leadership behavior with aspirations of the change, (3) ensure congruence at both business and change levels, (4) define and secure commitment through strategic interventions and (5) proactively manage organizational change by responding to "changing contingent circumstances". Empirical study conducted by Adenikinju and Olofin (2007) suggests that level of human capital; have a positive impact on growth in manufacturing, improvement in terms of trade and was found to have a beneficial impact on manufactures, but trade liberalization was insignificant, Akpan (2001). A pure desk research was conducted on industrialization and Nigeria's economic development. He posited that investment in physical capital, skill accumulation and utilization of existing technologies in the world, among other factors, will transform Nigeria's industrial sector. A qualitative government is essential in driving the industrialization-development nexus.

In support of industrial policy as a tool for achieving real economic growth Rodrik (2007), re-iterated the point that development is about structural change that comprises manufacturing new goods with new technologies and effecting reallocation (rechanneling) of scarce resources to productive areas. Governments should use industrial policy to effect necessary changes in the structure of the economy by transforming industries scales, expanding their economies and developing a tax base that can make these economies independent (Rowden, 2011) [20]. Whiles some have argued against these attempts at changing industrial structure, the work of (Khan, 2014) [21] shows that industrial policy can be necessary and an essential tool to modify economic activities, judging from the successful examples of the car and garment industries of India and Bangladesh respectively. As noted by World Bank (2002) [22], successful industrial policy in developing countries requires identifying, as well as harmonizing the determinants that contribute to industrial growth. Otalu and Anderu, (2015) [24] also identified capital, labour, exchange rate education, inflation rate, capacity utilization, trade openness and electricity generation as essential inputs into the industrial policy design model.

The creation of policy support system is an essential input factor for industrial policy effectiveness. As noted by Tsu-tan Fu, et. al (2014), the Hsin-Chu Science-based Industrial Park (HSIP) was founded for high-tech industries (ICT) in Taiwan. Initially Taiwan focused on light industries in the 1960s, which yielded an average GDP of $10.2 \%$ under an import substitution policy. This led to the rise of heavy and chemical industries in the 1970 s under an export promotion policy to export economic activities. Whiles the annual GDP reached $9.27 \%$ in the period leading to 1980 , the policy now focused on industrial technology upgrading to enable firms relocate to mainland China. The economic liberalization policy pursued in the period 1981 to 1990 rather recorded a decline in GDP growth to $7.37 \%$. However, this further went down to $3.76 \%$ from 2000 when industrial policy was focused on knowledgeintensive sectors, manufacturing and the service industry.

Create a link between knowledge acquisition, research and industrial application. Israel's success, especially after 1967, was hinged on its direct support for business firms towards research and innovation. Another factor is careful consideration of the contribution of the development of special social, economic and political factors affecting the country. Maturity of firms to take risks is another essential factor for industrial policy efficiency. This implies that enterprises operating in such industries should launch into new markets, launch new products, compete globally, sign across boundary partnership agreements for production, and/or supply of goods and services. Tied to this is the emergence of industry leader(s). An effective industrial policy will lead to emergence of industry leaders, product leaders and technology leaders. This gives some leverage or some level of comparative advantage. Another necessary input is the influence of positive externality. This requires a workable industrial change precipitated by positive externality. Positive externalities could be understood as effective management of 'spillover' effects in some cases. According to Tsu-tan Fu, et al. (2014), until 1980-2010, Taiwan's industrial policy targeted thirteen "hi-tech" industries with a strategy to establish science-oriented industrial incubations, provide technological 
support from research institutes, provide tax incentives and special support for developing semiconductor industry, among others.

Zelleke, Sraiheen \& Gupta (2013), used growth accounting approach to identify the sources of economic growth by resorting to the conceptual frameworks developed by Pritchett (2001) and Weil (2013), which show that human capital have positive effects in Sub-Saharan Africa (SSA) countries (they accounted for $22 \%$ of real GDP) but this is much lower than in high-income countries. Also, Otalu \& Keji (2015) long run empirical analysis using cointegration on Nigeria found physical capital and labour both have the expected positive significant impact on industrial output.
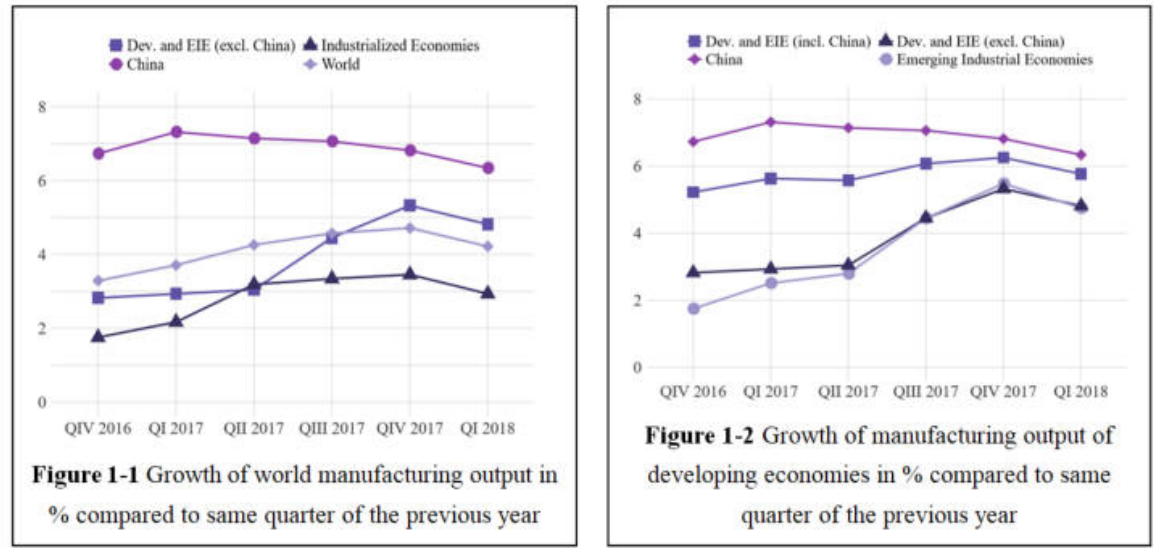

Source: UNIDO, World Manufacturing Production: Statistics for Quarter I, 2018 in Owoo \& Page (2017).

From Figures 1-1 and 1-2, compared to industrialized economies, developing and emerging economies have shown strong growth abilities in manufacturing activities. This achievement should be leveraged by developing economies by developing systems, policies and programs to sustain and boost the strong growth witnessed by the manufacturing sub-sector.

\subsection{Mechanisms for Industrial Change}

Successful mechanism calls for an action of response from both government and industrial organizations. Important questions would be (1) are policies of governments markets driven? (2) are the mechanisms used in the policy intended for government or the market? (3) are enterprise achievements connected to government or market mechanisms? (4) What are the advantages or disadvantages of such mechanisms (5) how to proceed from the establishment of the mechanism and (6) how should enterprises respond to such mechanisms?

An industrial change may be initiated for any or all of the following reasons: (i) demand side changes (ii) supply side changes (iii) market structure changes and (iv) to manage industrial scope or scale, but such change might be caused by the need for policy direction, technology for specific industries or reform of enterprise ownership. In addition, these kinds of changes might impact the whole economy, industrial organizations or specific enterprises in various industries. Industrial policy mechanisms are dimensional in nature. This comprises government tools, market tools and business tools. Ultimately, industrial change is necessitated to improve market mechanisms to economic management.

Unarguably, policy is one of the most effective factors for determining and measuring successful industrial change. It is essential to point out that the same policy, for instance, for an industry is likely to yield different results due to differences in enterprises within the same industry, in terms of size, capacity, level of technology, etc. this create a conundrum that needs further attention if policy as mechanism for initiating industrial change can be successful. This therefore requires promoting enterprise clusters, defining definite and specific actions and measures to help curb policy ineffectiveness. However, policy effectiveness should be measured in recognition of the broad and specific objectives of the mechanism, time span required, capacity and capability of affected industries or enterprises, stakeholders, general results and group of standards connected to achieving a mechanism and realization of the proceeds of the policy, which must be sustainable. Notwithstanding, whether a policy is government driven or market driven, policy must be made to reflect the real condition of the source of policy for which is designed. Page and Tarp (Eds.) (2017) were of the view that the focus of an industrial policy is to recognize and respond to needs that require public actions across different frontiers of the economy. 
To sum up the ideas on this part, policies should be developed on the basis of solving (i) employment and/or economic growth problems, that is, economic responsibility. In this case, governments should take leading role to ensure that these policies yield the intended results. (ii) Address legal challenges like tax evasion, environmental degradation, child trafficking, etc. (iii) Rectify some social issues, especially in places where enterprises are not be responsible enough to help develop the local economy. (iv) Market behavior challenges due to enterprise activities of dominating the market, collapsing other small enterprises or industries, making abnormal profits, etc. these will inform the kind of policy development approach that must be adopted and whether policy should be government targeted or market targeted.

\section{Analysis of the Industrial Sector of Ghana}

Table 1-1 Industrial Sector Performance, 1971-1983 (Average)

\begin{tabular}{lcccccr}
\hline Year & Real GDP & $\begin{array}{l}\text { Industrial } \\
\text { GDP }\end{array}$ & $\begin{array}{l}\text { Manufacturing } \\
\text { GDP }\end{array}$ & $\begin{array}{l}\text { Industrial } \\
\text { growth rate }\end{array}$ & $\begin{array}{l}\text { Manufacturing } \\
\text { growth rate }\end{array}$ & $\begin{array}{l}\text { GDP growth } \\
\text { rate }\end{array}$ \\
\cline { 2 - 5 } & \multicolumn{2}{r}{ (in Millions of 1975 cedis) } & & \\
\hline $1971-1979$ & 5492 & 1043.8 & 671.8 & -2.0 & -1.1 & 0.4 \\
$1980-1983$ & 5126.2 & 695.5 & 462.8 & -9.6 & -12.0 & -3.4 \\
\hline
\end{tabular}

Source: Aryeetey, Harrigan, and Nissanke (2000), GSS, Quarterly Digest Statistics, Various Issues

Table 1-2 Percentage Contribution of Industry to GDP, 1984-2000 (period averages)

\begin{tabular}{lllclc}
\hline Year & $\begin{array}{l}\text { Industry } \\
\text { \% of GDP) }\end{array}$ & $\begin{array}{l}\text { Contribution } \\
\text { of Manufacturing \& } \\
\text { Quarrying }\end{array}$ & Mining & $\begin{array}{l}\text { Electricity \& } \\
\text { Water }\end{array}$ & Construction \\
\hline $1984-90$ & 13.6 & 64.5 & 8.7 & 7.8 & 18.9 \\
$1991-5$ & 16.5 & 55 & 12.4 & 10.2 & 22.4 \\
$1996-2000$ & 25.2 & 36.2 & 22.6 & 10.5 & 30.7 \\
\hline
\end{tabular}

Source: National Accounts and State of the Economy (SGER)(ISSER 1991-2011)

Table 1-3 Industry share of GDP and sub-sector growth rates, 2001-2005 (\%)

\begin{tabular}{|c|c|c|c|c|c|c|}
\hline \multirow[b]{2}{*}{ Year } & \multirow[b]{2}{*}{$\begin{array}{l}\text { Total } \\
\text { Growth }\end{array}$} & \multicolumn{4}{|c|}{ Industry Sub-Sectors } & \multirow[b]{2}{*}{ Construction } \\
\hline & & Manufacturing & $\begin{array}{l}\text { Mining } \\
\text { Quarrying }\end{array}$ & $\&$ & $\begin{array}{l}\text { Electricity \& } \\
\text { Water }\end{array}$ & \\
\hline 2001 & 2.9 & 3.7 & -1.6 & & 4.0 & 4.8 \\
\hline 2002 & 4.7 & 4.8 & 4.5 & & 4.1 & 5.1 \\
\hline 2003 & 5.1 & 4.6 & 4.7 & & 4.2 & 6.1 \\
\hline 2004 & 5.1 & 4.7 & 4.5 & & 3.7 & 6.6 \\
\hline \multirow[t]{2}{*}{2005} & 7.6 & 5.0 & 6.3 & & 12.3 & 9.9 \\
\hline & $\begin{array}{l}\text { Industry ( } \% \text { of total } \\
\text { GDP) }\end{array}$ & \multicolumn{2}{|c|}{ Share of total industry } & & & \\
\hline 2001 & 24.9 & 36.7 & 21.1 & & 10.3 & 31.9 \\
\hline 2002 & 24.9 & 36.7 & 21.0 & & 10.3 & 32.0 \\
\hline 2003 & 24.9 & 36.6 & 21.0 & & 10.2 & 32.3 \\
\hline 2004 & 24.7 & 36.4 & 20.9 & & 10.1 & 32.7 \\
\hline 2005 & 24.7 & 36.3 & 20.4 & & 10.2 & 33.2 \\
\hline
\end{tabular}

Source: National Accounts and State of the Economy (SGER), (ISSER 1991-2011) 
Table 1-4 Industry share of GDP and sub-sector growth rates, 2006-2012 (\%)

\begin{tabular}{lllllll}
\hline \multirow{2}{*}{ Year } & \multicolumn{2}{c}{ Industry Sub-Sectors } & & & \\
& $\begin{array}{l}\text { Total Industry } \\
\text { Growth }\end{array}$ & Manufacturing & $\begin{array}{l}\text { Mining } \\
\text { Quarrying }\end{array}$ & Electricity & $\begin{array}{l}\text { Water } \\
\text { Sewerage }\end{array}$ & \& \\
\hline 2006 & 20.8 & 49.0 & 13.5 & 3.8 & 6.3 & 27.4 \\
2007 & 20.7 & 44.0 & 13.5 & 2.9 & 4.8 & 34.8 \\
2008 & 20.4 & 38.9 & 11.8 & 2.6 & 3.9 & 42.7 \\
2009 & 19.0 & 36.6 & 10.9 & 2.5 & 3.6 & 46.4 \\
2010 & 19.1 & 35.5 & 12.2 & 3.2 & 4.4 & 44.7 \\
2011 & 25.9 & 25.9 & 32.8 & 2.3 & 3.3 & 35.7 \\
2012 & 27.6 & 24.2 & 32.0 & 1.8 & 2.7 & 39.4 \\
\hline
\end{tabular}

Source: State of the Economy (SGER)(ISSER 2012); (GSS 2012); (MoFEP, various)

Tables 1-1 to 1-4 indicate the overall performance of the industrial sector of Ghana, and specific areas of measurement. It may be observed that the industrial sector for almost two decades (1970-1990) performed abysmally. Overall average for the period showed a weaker industrial base with low performances and negative growth in most periods. This may be attributed to several actors including lack of pragmatic industrial policy, poor leadership, absence of entrepreneurs and lack of SMEs, inappropriate support systems, structure of the economy and overdependence on state-led enterprises which were also in decline in terms of performance. However, the country has seen a more stable industrial sector in terms of growth. Particularly, the manufacturing sector has been growing at a steady pace although slow at some time periods.

\subsection{Challenges of the Manufacturing Sector in Ghana}

As has been noted in this paper, industrial policy is one of the most effective mechanisms to effect changes in industrial activities and productivity. An industrial policy therefore is designed to address challenges of manufacturing sector in terms of production, productivity and product quality (UNIDO, 2013). It has been noted that the manufacturing sector in Ghana has not taken full advantage of various economic and trade reforms that were promulgated, thereby, leading to low growth below targets. The challenges that has confronted the manufacturing sector include increased competition, high production and distribution cost (higher interest rates), over aged equipment in use, lack of necessary technology (inability to buy latest technology), inadequate infrastructure and services and low productivity (scale factor), lack of appropriate response to international markets - quality, style, design, timelines, sales support services, and inability to meet supply capacity.

The broad perspective of industrial change drive of Ghana was situated in the strategic vision, which was directed towards attaining middle income status by 2015. Thus, effect industrial changes to support job creation, employment generation, as well as achieving equitable and sustainable growth and development across the country. In order to attain sustained growth, the Ghana Poverty Reduction Strategy I (GPRS I) was established. Consequently, the Industrial Reform and Accelerated Growth Programme (IRAGP) under the ministry of Trade and Industry was also launched as a support tool for the GPRS I policy. The IRAGP was targeted at making Ghana agro-industrial base in Sub-Saharan African by 2015. This required boosting Ghana's GDP status from 5\% to 8\% per annum so as to attain per capita GDP of US\$1000 by the said year. To enable the private sector to take a lead in this direction, the Ghana Industrial Policy (GIP) was instituted as a means to increase manufacturing activities. The Trade Sector Support Programme (TSSP) with a five-year mandate (January 2006 to December 2010) was established as implementation mechanism. 
Table 1-5 Industrial Zoning Structure in Ghana

\begin{tabular}{|l|l|l|l|}
\hline Location & Group & Firm Size Range & Industrial Sector \\
\hline Kumasi & $\begin{array}{l}\text { Furniture Cluster } \\
\text { Suame-Magazine }\end{array}$ & $\begin{array}{l}\text { Micro-Small } \\
\text { Micro-Small }\end{array}$ & $\begin{array}{l}\text { Furniture } \\
\text { Metal Work and Machinery }\end{array}$ \\
\hline Tema & $\begin{array}{l}\text { Tema Industrial Area } \\
\text { Free Zones Enclave }\end{array}$ & $\begin{array}{l}\text { Small-Medium-Large } \\
\text { Small-Medium-Large }\end{array}$ & $\begin{array}{l}\text { All Sectors } \\
\text { All Sectors }\end{array}$ \\
\hline Accra & $\begin{array}{l}\text { Spintex industrial } \\
\text { area/Free zones enclave } \\
\text { North Industrial Area } \\
\text { South Industrial Area }\end{array}$ & $\begin{array}{l}\text { Small-Medium } \\
\text { Small-Medium } \\
\text { Small-Medium }\end{array}$ & $\begin{array}{l}\text { All Sectors } \\
\text { Manufacturing } \\
\text { Manufacturing and Garages }\end{array}$ \\
\hline $\begin{array}{l}\text { Sekondi/ } \\
\text { Takoradi }\end{array}$ & $\begin{array}{l}\text { Light Industrial Area } \\
\text { Light Industrial Area }\end{array}$ & Small-Medium-Large & $\begin{array}{l}\text { Manufacturing (mainly food } \\
\text { processing and wood exporters) } \\
\text { Garages-metalwork and machinery } \\
\text { Mineral processing for exports }\end{array}$ \\
& Heavy Industrial EPZ & Small-Medium-Large & \\
\hline
\end{tabular}

Source: Aryeetey, \& Kanbur (Eds), (2017)

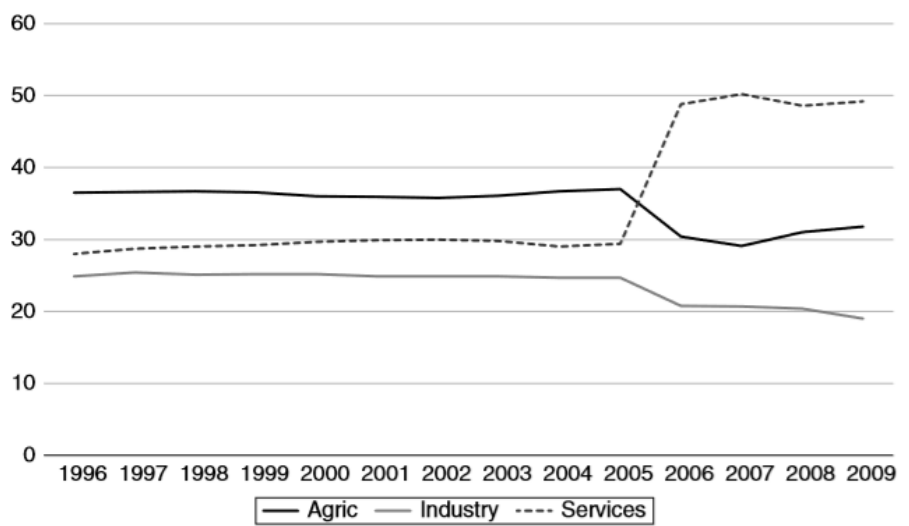

Figure 1-3 Contribution of Sectors to GDP, 1996-2009

Source: ISSER (2013)

From Figure 1-3, the industrial sector has continued to perform below the agriculture and service sectors. Without pragmatic steps to alter the structure of the Ghanaian economy, achieving industrial contribution of $7 \%$ per annum will be a mirage. This requires concerted efforts on the part of government, industrial sector and social institutions. Figure $\mathrm{xxx}$ on the other hand indicates that although Ghana has recorded negative GDP at some points in its development, the growth on average has been positive. It required that government will continue to drive investment through private sector initiatives both home and abroad to sustain and improve the gains made. 


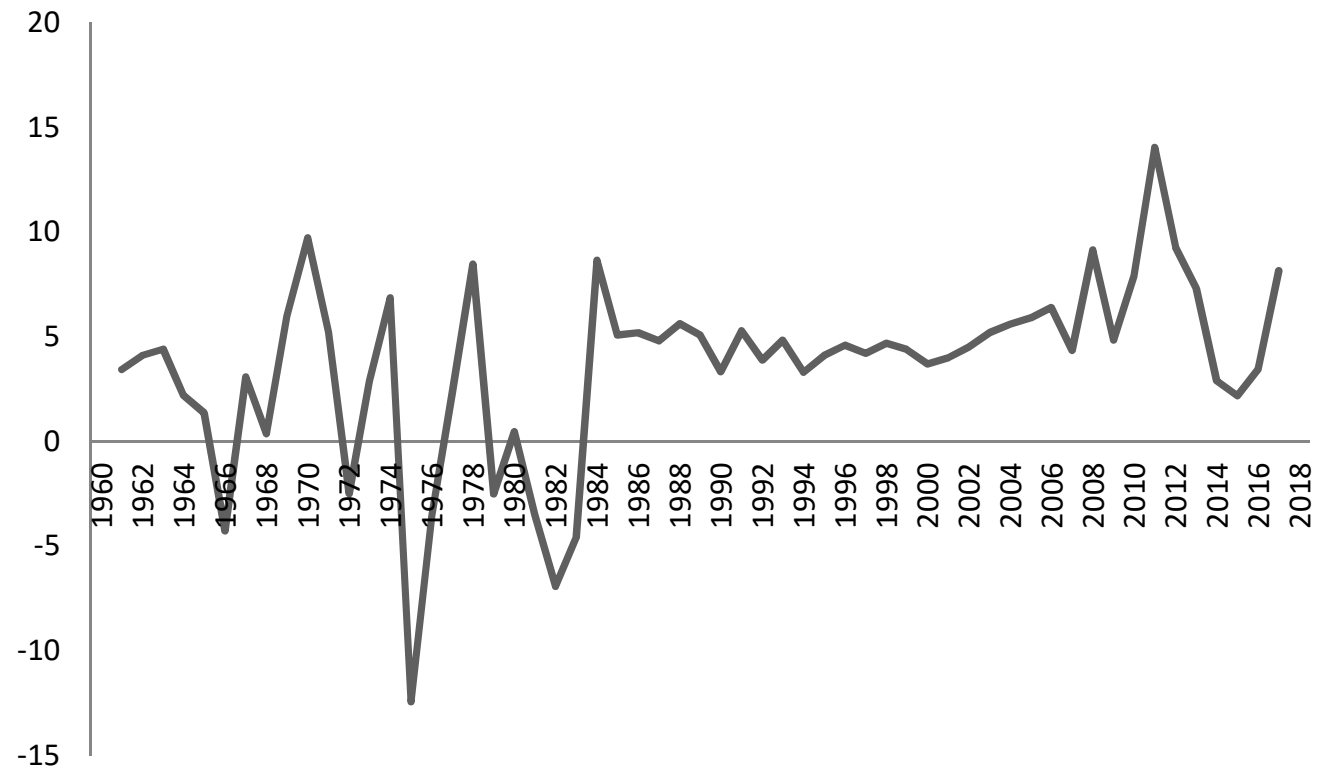

Figure 1-4 Ghana's GDP Growth Rate, 1960 - 2017

Data Source: World Bank

Macroeconomic development is essential for enhancing the rate of contribution of the industrial sector. Rodrik (2008), by using both inflation and terms of trade as additional exogenous covariates in a panel model to explain economic growth in manufacturing, found a negative and significant relationship between growth and inflation in developing countries. In the same way, Greenwald and Stiglitz (2006) proved that in developing countries, low exchange rates help export sectors like manufacturing to compete, especially sectors which have higher learning elasticities and generate more learning externalities.

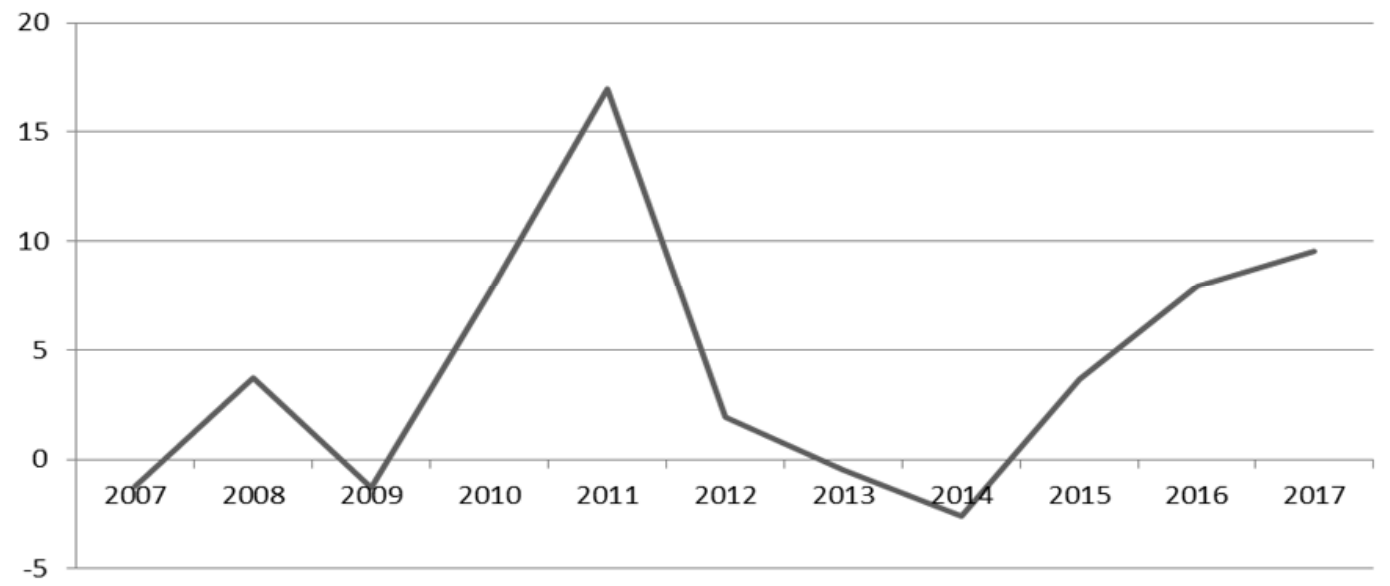

Figure 1-5 Ghana's Manufacturing Performance, 2007 - 2017

Data Source: World Bank

Since 2007 to 2017, the manufacturing sector of Ghana grew at an average rate of $4.16 \%$. Although this is rather low in helping the country to move up the ladder of developed economies, it is significant achievement that must be leveraged. This will ensure that the industrial sector is able to achieve the $7 \%$ benchmark.

\section{Proposed Conceptual Model for Ghana}

This research to a large extent has argued that a successful industrial change is fundamentally hinged on change 
in industrial policy. This is the greatest tool available to governments to ensure the industrial sector is robust so as to contribute to its economic and development agenda. An industrial policy that results in successful industrial change must result in increased total factor productivity, business and socio-economic development. To this end, policy has an overarching role in activities expected from both government and industry. According to the World Bank (2002), formulation of policies that integrates, harmonizes and identifies industrial output factors is bedrock to industrial change success. This implies that policy design and convergence are essential in ensuring industrial policy succeeds. Disjointed policies can only achieve some targets at the micro level (policy specific areas). However, an industrial policy design requires synchronizing all related policy areas to ensure smooth attainment of intended broad goals. For example, an industrial policy will require strong backing of educational and research institutions due to their strategic role in supplying new and improved knowledge and high quality human capital needed to drive the intended industrialization. Also, close collaboration with industry for which the policies are intended will add value to policies. Industry understands the challenges and grounds issues that must necessitate policy design better. It can be argued that an industrial change that aims at achieving high total factor productivity or contribution to GDP above the industry benchmark of $7 \%$ could be considered from different perspectives. In this broader sense, successful industrial change requires two main principal actors - government mechanism and industry mechanism (Figure 1-8). However, social factors and SMEs development are also essential tools for propelling successful industrial change.

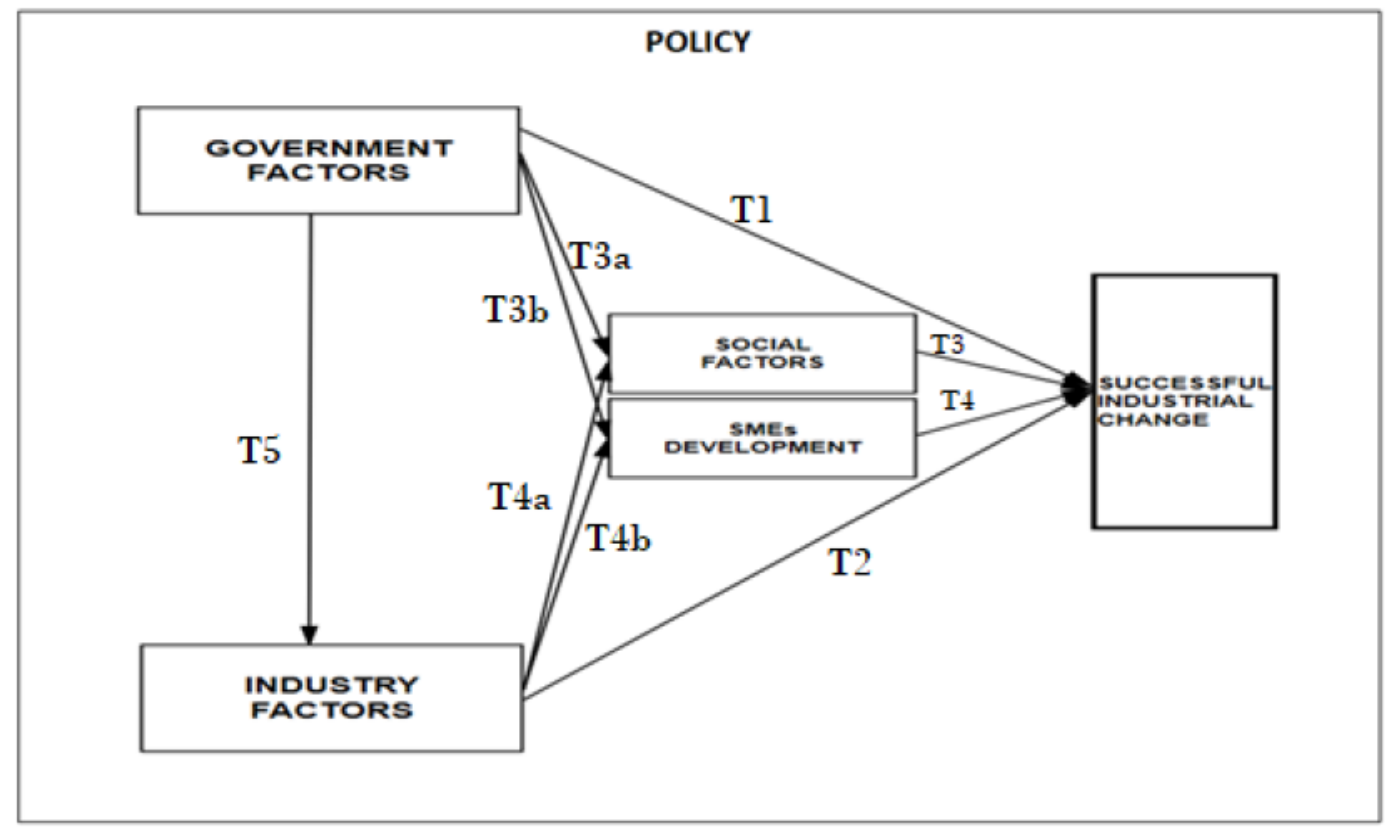

Figure 1- 6 EKs successful industrial change model

First, since government is the main stakeholder in industrialization drive, government could undertake certain drives and initiatives that focus directly on boosting industrial output, using route T1. For example, the supply of cocoa beans and chemicals to farmers in Ghana were in lieu of high cocoa yields. Other ways government could influence successful industrial change is through paths T3a and T3b in the form of stimulating a change in certain social factors and SMEs development. In respect of social factors and SMEs development, industry could similarly enforce changes to ensure effective industrial change (represented by T4a and T4b). Path (T2) shows the effects of industry mechanism on arriving at successful industrial change. Markets need to respond positively through deliberate actions to ensure industrial change yields the intended outcomes. Path T5 shows how government can enforce successful industrial change by undertaking certain actions to improve the performance of industry. These are expanded in detail from Figure 1-9. Porter argued that nations can improve their competitive advantage position through production factors, demand driven situation, industry support system and conduct, structure and competition by firms (Porter, 1990). 


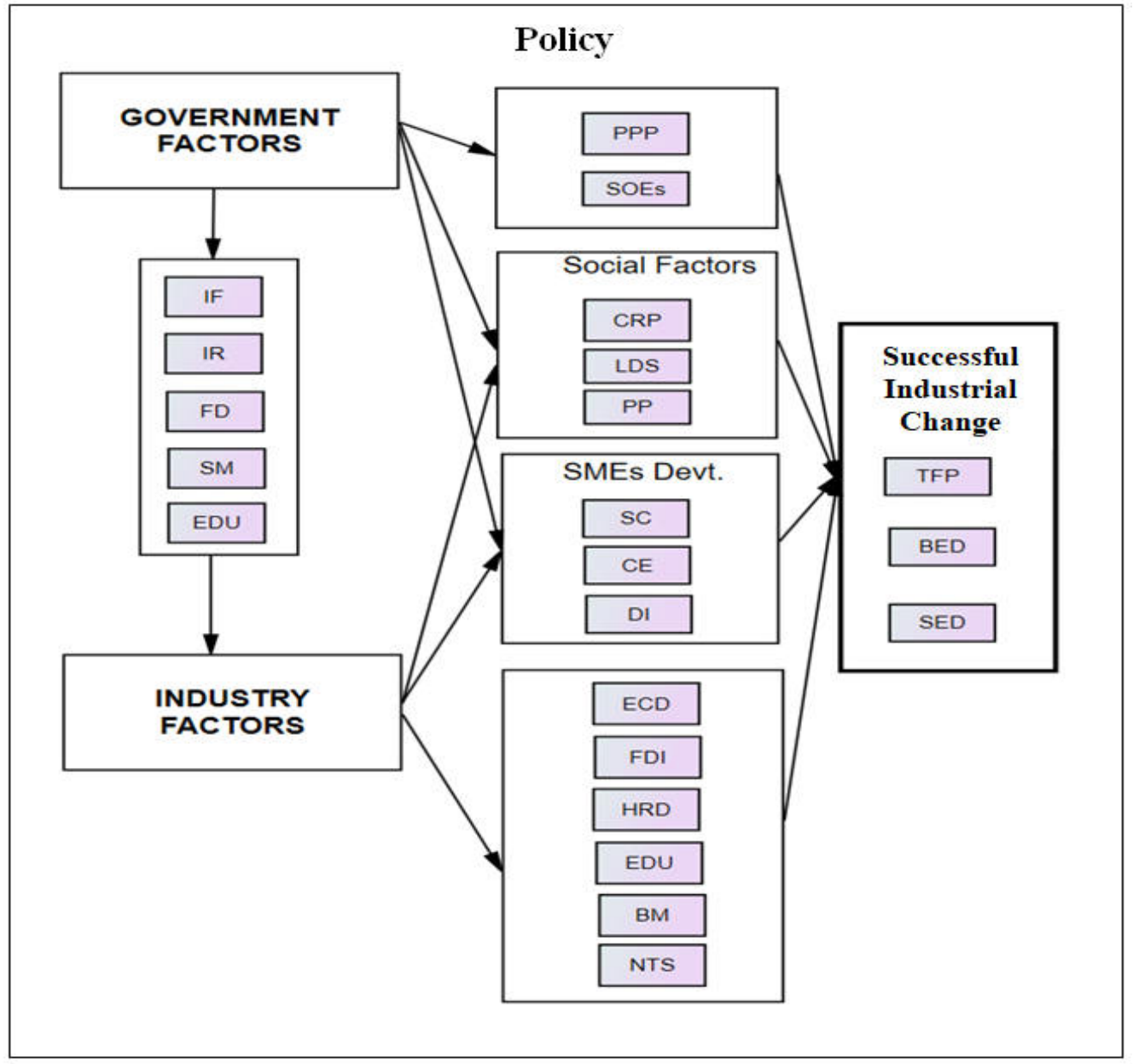

Figure 1-7 EKs successful industrial change model (Expanded)

\subsection{Government Factors}

Direct government action (T1) in the form of public private partnership (PPP) and State Owned Enterprises (SOEs) (Figure 1-9) are means by which government can directly change industrial structure. The industrialization drive of Ghana between 1957 and 1967 were driven by government led establishment of state own enterprises (SOEs). Although and PPP and SOEs have been successfully implemented in other countries, Ghana is yet to realize the full potentials of such intervention on industrial success. Establishment of SOEs which was the main driving force of industrial and economic change in Ghana at independence was abandoned by subsequent governments. Now, country detests the establishment of enterprises by government due to its capital economy nature. But certain strategic areas really need the direct intervention of the government to ensure that the industrial sector grows above the industry average of $7 \%$ that is required to ensure the country continues on a successful industrial path. Sectors such as water and electricity supply, cyber systems, security, ports and harbors management and airline operation are among some areas that government should directly invest in.

\subsubsection{Infrastructural Development}

Infrastructural development (IFD) as revealed in Figure 1-7 is related to locational activities among other factors. Otalu and Keji (2015) believe physical capital influences industrial output positively. Social capital in the form of roads, schools, hospitals, and other essential services are in high demand if industrial policy driven by industrial location will be workable. However, this calls for close collaboration between government and private sector considering that there are scarce resources on the part of the government. Other forms of infrastructures required are information and communication system, internet system, telecommunication system, e-services backed by high 
security measures to avoid asset losses over the internet and incubation parks. Unsatisfactory performance of the industrial sector has been the result of lack of, inadequate and deteriorating state of infrastructure - power and transportation bottlenecks, handling facilities at ports. Funds - capital market helps to mobilize private funds for private sector expansionary activities. The country needs to ensure adequate infrastructure for effective internet connectivity country-wide and also provide these at cheaper rates. Industrial zoning (clusters), another means of infrastructural development, is essential for industrial success. Location is determined by availability of labor, supply of raw materials, access market centers, ease of transportation, access to energy and water supply services (Ben-Zvi, 1981). Ghana is endowed with essential natural resources at various locations in the country. Leveraging on the activities of the Ghana Free Zones Board (GFZB), strategic steps need to be taken in industrial policy design to build certain industries at selected locations in the country Midelfart-Knarvik, Overman, Redding, \& Venables (2000). Mining companies have been very strategic in this regard although minerals extracted from the communities are not processed there but exported in their raw state. Similarly, there is no value-addition company in the cocoa industry that is situated in cocoa growing areas. Whiles this increases the cost of adding value to products from such resources, it is also disincentive to locals and suppliers of such raw materials because their areas do not see any improvement Ackah, Adjasi and Turkson (2016).

\subsubsection{Institutional Reform and Development}

Industrial design and implemented should not be on "trial and error" basis (Rodrik, 2008. Therefore, it is expected of the government to continue the institutional reform and development (IRD) (Figure 1-9) program started under the Kufour administration. This also requires industrial policies to be forward looking and should include an exit strategy. According to Evans (1995, chap. 1) and Acemoglu \& Robinson (2008), institutions are broadly play a pivotal role in differences in economic growth and development. "Industrial development is considered necessary to achieve high rate of economic growth, to provide for the basic needs of population, to lead to an increasingly diversified economy and to give rise to social psychology and institutional changes." (Sharma, 2014). The Public Sector Reform that was started under the Kufour led government need to be continued to make public sector institutions relevant to the national development discourse. Also, the digitization process which has been intensified under the Akufo-Addo led government should be carried through. This will make it easy to access services, reduce corruption and fast track acquisition of essential services.

\subsubsection{Support Mechanism}

As revealed in Figure 1-7, support mechanisms (SM) should be developed to sustain gains from industrial changes. Like the US, the Administrator of the Small Business Administration reports directly to the President of the United States as a means of ensuring it get the necessary impetus from central government. Support mechanisms are relevant and critical for continuous development and survival of developing industries. These will ensure the success of any industrial change initiative. Some institutions were established on the basis of legal instruments, but others were only established as policy implementation and market development institutions. Enterprises and legislations such as the Business Assistance Fund (BAF) was established in 1993, the PEED policy in 1994, the investment policy Fund for Small and Medium Scale Enterprises Development (FUSMED) in 1990 intended to provide funds to help increase industrial production; the GIPC Act of 1994 to PNDC Law 116 was instituted to drive investment and the Ghana Investment Code (GIC), the Ghana Trade and Investment Gateway Programme (GHATIG) in 1996 and the Ghana Free Zones Board (GFZB) in 1995.

\subsubsection{Education}

As has been generally agreed, increases in advanced knowledge have positive and significant relationship with industrial development. This requires a vibrant education (EDU) sector as in Figure 1-7 that embraces three aspects - research and development $(\mathrm{R} \& \mathrm{D})$, educational training alignment and quality training. Ghana must take appropriate steps to enforce industry-research and linkage of academic institutions to industry to harness the great potentials of sustainable industrialization. Industry driven research has the potential to make available knowledge and technology needed by the private sector to innovate (Hottenrott \& Thorwarth, 2011). New discoveries can enable industry to harness their new products and access new markets. R\&D continues to serve as strong basis for industrial change and leads the debate on both high tech, innovation and industrialization drive that yields the intended TFP. It also serves as a tool for ensuring sustainable and quality industrialization, which is a bed rock for sustainable socio-economic development. This calls for strong linkage between industry and research institutions, 
as well as universities. An effective collaboration of this nature will help to attain $\mathrm{n}$ industrial output over and above the benchmark. Educational training should be aligned to industrial development. Government should undertake changes in educational policies to ensure continuous supply of quality and essential human resources to industry. Universities and training institutions should be encouraged to undertake special courses intended to supply specific human resource to industry. Academic programs should incorporate industry applicability to ensure that the needs of enterprises are being addressed. There could be a short term approach or a long term approach. A short term approach would mean government can target institutions of higher learning by way of policies that are intended to ensure there are necessary human resources for industry. This also requires establishing universities according to specialization to help develop suitable and needed skills for industry; otherwise, training human resources without requisite need for their services is a social cost to the state. A different approach, long term tool, implies a complete overhaul of the educational system. In this case, the government needs to remodel the education system from pre-school to university. This is intended to ensure that there is consistency in what students are exposed to from their formative years to institutions of higher learning. Quality training should be the focused of educational program intended to effect positive changes in industrial sector Marimuthu, Arokiasamy and Ismail, 2009; Rastogi (2000). Quality training continue to face challenges continue to persist. Multiple factors contribute to this problem. First, lack of infrastructure to accommodate the large number of students who gain admissions into the universities is still pervasive. Second, inadequate study materials continue pose huge risk to effective learning. The universities lack modern libraries, and science and computer laboratories that can facilitate self-study and effective research. Thirdly, there is lack of effective supervision in education. This is partly due to the large number of students, lack of facilities and also some professors are multi-task. Furthermore, the absence of industrial practice to enhance the skills of students has deepened the student-quality problem (SQP). These challenges must be addressed with immediate effect if the country can rely on its human resources to produce goods and services that can compete in the international market.

\subsubsection{Funding}

Funding (FD) (Figure 1-7) by Government to promote industrial change success has several dimensions. This could be in the form of research funding, support institutions funding and stimulus packages. The Government of Ghana should continue to fund national research institutions such as the Council for Scientific and Industrial Research, Forestry Research Institute, Institute of Statistical and Economic Research and Advanced Technology Institute, among others. This will ensure the availability of advanced knowledge that could be accessed by private enterprises that do not have the capability to conduct their own researches or contract special researches institutions to undertake such activities. Similarly, government should provide funding support for technical and industrial development oriented organizations such as the Business Assistance Fund (BAF), the Private Enterprise and Export Development Fund (PEED), the Trade and Investment Programme (TIP), the Fund for Small and Medium Enterprises Development, the Export Processing Zone (EPZ), and the Ghana Trade and Investment Gateway project (GHATIG) and the GRATIS Foundation. This will enable them to continuously provide needed support for industrial development. This will be able to train and consult for industrial organizations in respect of new processes, products, markets and skills required by the private sector enterprises. In the case of the US financial crunch, the government provided funding support to revamp certain industries and enterprises. In the case of Ghana, the cocoa sector and by extension, the agricultural sector has benefited from a number of government funding support in the form of seedlings, fertilizers, extension services, etc. The government should however design pragmatic procedure for accessing these funds.

\subsubsection{Trade Agreements and Partnerships}

In 1965, the General Agreement on Tariffs and Trade (GATT) was amended to recognize the special economic needs of developing countries and establish the non-reciprocity principle. In 1968, UNCTAD was also established to further the collective interest of required in international trade. The government of Ghana should continue to promote and collaborate in bilateral, multilateral and global trade agreements (TA) as shown in Figure 1-9 that can safe guard the interest of local industries. For example, the institution of Africa Growth and Opportunities Act (AGOA) and New Partnership for Africa's Development (AUDC-NEPAD) provides access for Ghanaian enterprises to get access to US markets in related commodities, and to facilitate Africa's development through consolidation of Markets, financial systems, transportation, among others. The example of Belt and Road Forum (BRF) initiated by the Chinese government is also remarkable and commendable. The government should however, take steps to withdraw from all agreements which do not yield any benefits to local industries but rather cripple 
them.

\subsection{Industry Factors}

Business models, creation and expansion of markets internationally and active international trade participation, continuous supply of new technology and input materials, enterprise capacity development and human resource development are essentials features that can ensure the success of industrial policies. Drucker's idea about the role or innovation and entrepreneurship did not surpass his strong view about the influence of management in a systemic way to produce results that is in dire need by modern society. Institutions function as organs of society to produce results, and "management is the specific function and specific instrument to make institutions capable of producing results." Drucker (2004).

\subsubsection{Business Model}

Efforts of the government must be compensated by effective industry practices. In a mixed market economic system, governments are limited in the extent to which they can undertake activities geared towards realizing private profits. An industrialization drive intended to achieve high TFP should usher in revision of business models. Businesses must therefore be adaptable to adopt new changes that require an overhaul in the kind of business model (BM) under operation. This calls for re-strategizing and re-positioning to take advantage of new policies promulgated by the government. Without market expansion, industrial change activities will be stifled. Industry should expand their business model to cover global market space. International trade and market creation require change in business model in line with government policy on business activities. Policy design could be preceded by availability of markets for goods and services. This is the responsibility of both market forces and government. There are however two perspectives to the market - international trade and creation of new local markets. Enterprises could be assisted to launch their products and services into new markets through government facilitation, market research and training. It could be facilitated where industry has comparative advantage as a result of the type and level of technology, quality of products and ability to meet capacity demands. The industrialization drive by some East Asian countries, particularly China, followed this pattern. China had comparative advantage in labour market and raw materials thereby designing policies to guide particular industries and sectors in respect of FDI influx.

\subsubsection{Foreign Direct Investment}

Foreign direct investment (FDI) does not only require government efforts, but industry activities as shown in Figure 1-9. Industry requires new technology and raw materials to sustain the pace of industrial change. FDI can be obtained through direct acquisition from a patented enterprise from within a country or outside, joint 'ventureship', knowledge sharing through industry associations, trade exhibitions and professional networks. Raw materials could be attained by citing industries near resource locations, ensuring easy transportation of raw materials to industrial hubs or undertaking international sourcing. Without adequate resources, industrial drives may be forestalled. However, as in the case of United Arab Emirates, proper estimation of a particular resource can lead to effective diversification at an appropriate future, which must be incorporated into industrial policy design.

\subsubsection{Enterprise Capacity Development}

Industrial organizations should develop their capacities to ensure they are able to take advantage of the growing sound macro-economic environment the country offers. As has been indicated above, industrial organizations have contributed to the GDP growth of the country but this has been below the industry threshold of 7\%. These are not only as a result of inappropriate or negative policies, or lack of support from government, but the inability and low capacity, of industries to take advantage of growing opportunities. This requires building financial capacity, develop supply chain networks, acquire new technologies, expand infrastructure and credit contracts. As noted by Affum (2019) in respect of the capacity of the foodservice sub industry, low capacity inhibits innovation in the industry. This will ensure continuous development that will plunge these enterprises into success. 


\subsubsection{Human Resource Development}

Since it is generally agreed that human resource development (HRD) contributed significantly and positively to economic growth. Hence, industry needs to develop the human resource capacity of employees. This could happen by a combination of several factors - on the job, staff meetings and briefings, attending conferences and participation in trade exhibition and activities of industry associations. Through these activities, employees will be exposed to new knowledge in related field and technologies that can improve on work and work processes. This will ultimately lead to industrial change success that is required to boost contribution of industry to overall productivity and socio-economic growth, as well as business development.

\subsubsection{Education}

Industry can indirectly use education to ensure industry change success. This could be done through establishment of own research centers as in the case of Huawei and other global entities, research funding support to academic and research institutions, policy to absorb graduates with certain degrees from specific universities on internship basis or full employments and provision of infrastructural support to academic institutions. Additionally, industry could also make available their facilities to help in research activities. Through these initiatives, industry can be sure of the quality of human resource that will be employed and researches that are undertaken.

\subsubsection{New technologies and Materials}

An industrial change that is expected to succeed requires necessary changes in industrial structure and industrial activities. An essential element of industrial success is new technology and raw materials base. New technology can be acquired through intra or inter industry activities. Industry is expected to have a new view of how things should work in line with new expectations propelled by overall national industry development policy. One of the essential aspects of industrial development is new technology and materials. This implies that industry should have innovative view of issues. That means new technologies; processes and materials should be embraced to enhance industrial output. This sometimes calls for diversification of certain aspects or all of industrial operations. Industry could also use vertical, horizontal, cross border or technical integration (Shepherd \& Wilcox (1979, p. 164-165) to acquire new technology and materials. The goal should be to expand industrial output, ensure business expansion and contribute to socio-economic development.

\subsection{Social factors}

The success of industrial change necessitated by industrial policy change is not only the result of a chain of direct industrial activities and effective government interventions. It also hinges of social cohesion and stability. There certain social phenomenon in developing countries that cannot be treated as isolated issues. Without close attention to address these issues head-on, they stand high chance of subverting any form of industrial changes. Three of such issues that are critical in the case of Ghana are corruption, leadership and partisan politics.

\subsubsection{Corruption}

Corruption (CRP) has been widely considered as an inimical tool to businesses, economic and national development. Corruption has different forms and multiple impacts. Generally, developing countries are high on the corruption perception index. This has multiple effects on the economy. Principally, corruption affects private and public sectors alike. As stated earlier, corruption reduces industrial output and stifles SME development in spite of the critical role SMEs occupy in national economic affairs. According to UNIDO \& UNODC (2012), SMEs profits are negatively affected due to the prevalence of corruption. Additionally, corruption also reduces the foreign direct investment flow (FDI) into a country. Countries might experience decreased domestic investment when human capital is low, but the incidence of corruption is high (Kim, et al 2013). An industrial policy that is hinged on SME development will be vanquished at the instance of high corruption. Corruption can be eliminated by fair policy administration. Policies should be administered on the basis of non-discrimination, non-partisan, and not on family lines (Barnett \& Ganz 2018; Baumol, 1990; Murphy, Shleifer \& Vishny, 1993; Svensson, 2005). Decrease industrial regeneration distorts the allocation of resources, inhibit productive activity and promotes organizational failure (Acemoglu et al., 2005; Hafner et al., 2016; Klapper et al., 2010; Rose-Ackerman and Palifka, 2016). 


\subsubsection{Partisan Politics}

In Ghana, partisan politics (PP) has taken center stage in national discourse and has had great impact on both national development and industrial practices. Although Ghana has made huge progress in its political development, having witnessed four smooth transition of political power since 1992, still continues to grapple with the negative role of politics even in its stable political system. Unfortunately, politics in Ghana has taken preeminence over sound policy direction initiated by technocrats and bureaucrats. Most industrial policies have become a lure for political power and sustenance of political legitimacy. Policies in general have suffered "job for the boys" concept as it is usually intended to create jobs for party people who do not possess necessary qualification or requisite experience. The effect has been that policy design, implementation and monitoring and evaluation (M\&E) are considered on partisan political lines which only end up in fruitless debates without necessary action to solve problems or increase TFP. Ultimately, good and well-intended policies are aborted with the passing of a political party from government. Governments should seek to promote policies on dispassionate and purely intellectual thinking realms to ensure that they are reliable and sustainable with the passage of a government and instills confidence in policy users.

\subsubsection{Leadership}

The influence of leadership in industrial change success cannot be over-emphasized. Clague et al (1997), proved that differences across countries in property relations and contract enforcement lead to high transaction costs and thus have a negative impact on growth. Similarly, $\mathrm{Ng}$ and Yeats (1999) found that governance regulations (plus national trade) explain over 60 percent of the variance in some measures of economic performance and thus, a country's own national policies shape its rate of development, industrialization, and growth. The Chinese 5-year development plan provides direction to all Chinese leaders, in spite of the person in the seat of presidency or what economic policies may be brought on board. Once the development plan has been finalized, the next step to ensure they achieve the intended goals is implementation through institutional alignment to policy changes. This requires institutional leaders to ensure that they fully understand the tenets of the development plan, thereby, design policies and programs aimed at achieving objectives set out in the development plan. In the African context, however, political system alignment to the direction of industrialization is highly essential but lacking. Ghana, for instance has the National Development Planning Commission (NDPC), but most of the policies and programs that are designed do not transcend a political regime. This makes it difficult for development agendas to be attained through industrial policy changes simply because they are inconsistent. Industrial policy practice successes in certain places can be directly traced to the influence of leadership. Leadership in this case must be understood from two perspectives - political leadership (policy design, policy direction and policy goals setting) and institutional leadership (the supply of technical - technocratic skills required to translate policy into programs and to implement policies according to the design, whiles conducting monitoring and evaluation). Ghana saw much revolution in the industrial sector under the leadership of Dr. Kwame Nkrumah. Subsequently, these saw problems and the country declined after the first few years of its independence due to changes in leadership.

\subsection{SMEs Development Factors}

Development of Small and Medium Sized enterprises have become the new paradigm for industrial drive. Unfortunately, there has not been considerable attention given to this sector of the economy. As noted, SMEs accounted for about $90 \%$ of manufacturing jobs in Ghana and the pathway to radical and sustainable socioeconomic development (Affum, 2015). It has been largely considered by several countries to be the back bone or engine of economy growth. Even in advanced countries, SMEs have led the path to innovations. In the European economic bloc, as noted by Hart (The Banker, 2013), 99.8\% of all companies and two-thirds of employment were provided by SMEs. In the Food industry for instance, SMEs accounted for $48.7 \%$ of turnover and employment of $63.0 \%$ in food and drinks alone (The EU, 2009). Similarly, SMEs accounted for $99.2 \%$ of total number of enterprises, whiles contributing about 32\% to GDP and 59\% to employment in Malaysia (SME Report 2010/2011, cited in Arshad and Rasfi, 2013). SMEs in Japan however usually play an indirect role by supplying low-cost and high-quality equipment parts to big firms. It is imperative for the government of Ghana to factor SMEs development into any industrial policy design and implementation. Whiles large firms possess capital, human resources and market advantages, SMEs continue to champion the spate of economic growth in most developing countries. This therefore calls for re-aligning the structure of the Ghanaian economy to shift some resources from large firms to small enterprises, as a strategic means of boosting industrial output. There are pragmatic activities that should be undertaken to realize this goal. These are supplier contracts, credit extension (financial inclusion) 
and direct investment.

\subsubsection{Supply Contracts}

Both government and large firms should deliberately allocate some supply contracts (SC) to small businesses. For instance, the policy of local content that was being practiced should be incorporated into development documents of the government to make them deliberate and mandatory for large firms that win huge contracts, especially from government, to give certain aspects in terms of supply of services and materials to small businesses. Government should design a threshold in this regard. Additionally, government procurement should have a percentage reserved for small businesses in an attempt to ensure SMEs development as a tool for boosting industrial productivity and developing local capacity to ensure industrial change sustenance, especially in the case of spill-overs. This can have both direct and indirect contribution to industrial change success. Similarly, large firms should also be required to reserve portions of their supply contracts to small business on a fair-competitive basis.

\subsubsection{Credit Extension}

As part of developing the capacities of SMEs to enhance their ability to effectively contribute to industrial success, there is need to empower SMEs financially. One of the soft approaches to this is through credit extension (CE). The practice in Ghana is however the reverse. Many SMEs are handicapped because both government and corporate Ghana require SMEs to supply goods and services by providing 30 to 90 days credit. This stifles business development, especially among SMEs. Governments and large firms should rather support SMEs with credit financing. This will enable the SMEs sector to develop financial capacity to take on large contracts. Additionally, the government needs to work at improving the financial inclusion of SMEs in mainstream banking activities.

\subsubsection{Direct investment}

Another approach to developing SMEs as a means of industrial change success is through direct investment (Div). Industrial organizations should directly invest in SMEs instead of only investing in entities on the stock exchange. This way of investment can be conducted through vertical or horizontal integrations or acquisitions to make them sustainable to facilitate the rate of industrial development and enterprises that can absorb any spill overs that may occur through industrial heating. On the part of government, this could be in the form of funding support in necessary supports such as activities of the Skills Development Fund (SDF) Business Development Services (BDS), National Board for Small Scale Industry (NBSSI)

\subsection{Conclusion and Recommendations}

The role of industrial policy in driving economic growth cannot be overlooked if Ghana intends to achieve a high middle income country status in the foreseeable future. Achieving total factor productivity that is above the industry average is not entirely unrealistic. The examples of Taiwan and some East Asian countries like China, Japan, South Korea, Vietnam, Cambodia, to mention a few are instructive for any economy that hopes to bring itself out of low economic productivity. As stated in this paper, an industrial policy could be structural change or fundamental change targeted. However, as argued by some scholars the best approach to achieve fast-paced economic growth is through a structural change that ensures realignment of economic resources to sector needs, although some scholars have argued that an industrial policy does not lead to structural change. It is also fair to note that, a structural change that does not have fundamental change of the economy incorporated in it is likely to deliver productivity without quality. The current government of Ghana has embarked on industrial acceleration programs enrolled on the wheels of the 'one district, one factory' and 'one village, one dam'. At the same time, there is an active program in place geared towards ensuring a total public sector reform undertaken through various e-services and free education. As laudable as they might seem, they are demanding in terms of human resource capacity, financial and material resources if these are to succeed. Ghana should therefore strengthen its policy relatedness.

It is therefore expected that the government can undertake these activities systematically by first focusing on the capital intensive projects of 'one district, one factory' and then move on to extensive public sector reform as a means of sustaining the industrialization drive. Also, these programs of action require strong policy support backed by the National Development Planning Commission. The government must also take steps to improve on the tax administration in the country. This is not a call for increased tax but ensuring quality tax which requires that all 
institutions that are to pay taxes pay appropriate taxes. Government should also eliminate political biases that impede policy design, implementation and monitoring in the country by following due procedures. The ruling government should endeavour to achieve political consensus on such matters. The government must continue to rely on corruption expose activities through the work of investigative journalist, Anas Arimeyaw Anas, since corruption has over the years proven to be a critical negative variable that reduces achievement of policies, programs and economic growth in the country. Punitive measures must be enacted to deal with corrupt cases, whiles the courts should be well resourced to dispose such cases within a reasonable space of time. Another important concern is for the government to ensure to achieve policy congruence through alignment of education and industry policies and programs studies in universities. There is the need for policies to encompass academic and research institutions, industry and government. One-sided policy design, implementation and monitoring is not sustainable and they are bound to fail miserably. An important component required for effective working of industrial policy is monitoring and evaluation mechanisms. This must be incorporated into the policy design. The continuation or otherwise of an industrial policy should be based on effective monitoring and evaluation assessment and reporting. Within an industrial policy framework, there is the need to factor in permanency or discontinuation of such policies. Governments should not view industrial policy as an end in themselves due to the amount of funds or time invested into such activities.

The limitation of this research is quite obvious. The analysis conducted here are not empirically based, hence, the need for further research to test the potency of the proposed model using empirical data.

\section{Conflict of Interest}

There is no conflict of interest with any financial organization or among authors regarding the content of the manuscript.

\section{Acknowledgement}

The authors gratefully acknowledge the support provided by Weixin Zeng ( $\mathrm{PhD}$.), Gaige Tu (PhD.) and Abdul Hamid Kwarteng (PhD.) who offered valuable suggestions on the draft paper.

\section{References}

Ackah, C. Adjasi, C \& Turkson, F. (2016). Industrial Policy in Ghana: Its Evolution and Impact. DOI:10.1093/acprof:oso/9780198776987.003.0003 Eds. Carol Newman, John Page, John Rand, Abebe Shimeles, Måns Söderbom, and Finn Tarp (In: Manufacturing Transformation: Comparative Studies of Industrial Development in Africa and Emerging Asia. University Press Scholarship Online Oxford Scholarship Online. DOI: 10.1093/acprof:oso/9780198776987.001.0001

Acemoglu, D., Johnson, S. \& Robinson, J. A. (2005). Institutions as a Fundamental Cause of Long-Run Growth. pp. 385-472 in Handbook of Economic Growth. Vol. 1, edited by Aghion, P. and Durlauf. S. N. Elsevier.

Acemoglu, D. \& Robinson, J. A. (2008). The Role of Institutions in Growth and Development. Working Paper NO. 3. Commission on Growth and Development. The International Bank for Reconstruction and Development/The World Bank

Adenikinju \& Olofin (2000). Economic Policy and Manufacturing sector performance in Africa. The Nigerian Journal of Economic and Social Studies 42 (1): 1-22

Affum, E. K. (2015). The Socio-economic Impact of SMEs Development on China and Ghana. Thesis submitted to the Graduate School of Business (MBA School) of Zhongnan University of Economics and Law in partial fulfillment of the requirements for the award of Master of Business Administration (MBA) degree.

Affum, E. K. (2019). Design and application of analytical framework for innovation in the traditional industry in Ghana: a study based on the foodservice industry. Dissertation submitted to the School of Business Administration, Zhongnan University of Economics and Law in partial fulfillment of the requirements for the award of doctoral degree.

Akpan, H. E. (2001). Industralisation and Nigeria's Economic Development. Nigerian Economic Society Publication.

Arrighi, G., Silver, B. J. and Brewer, B. D. (2003). Industrial Convergence, Globalization, and the Persistence of the North-South Divide. Studies in Comparative International Development / Spring 2003 
Aryeetey E. and Fenny A. P. (2017). Economic Growth in Ghana: Trends and Structure, 1960-2014. The Economy of Ghana Sixty Years after Independence (2017). Eds ERNEST ARYEETEY and RAVI KANBUR. Oxford University Press. Pp. 45-65

Babbie, E (2004). The practice of social research, Belmont, CA: Wads-Worth.

Backer, E. \& Barry, B. (2013). Empirical testing of the theory of partial industrialisation in tourism. Journal of Hospitality and Tourism Management, 20, 43-52. doi:10.1016/j.jhtm.2013.06.001

Bain, J. S. (1968). Industrial Organization. 2nd edition. New York: John Wiley \& Sons, Inc.

Barberia, L. G. \& Biderman, C. (2010). Local economic development: Theory, evidence, and implications for policy in Brazil. Geoforum, 41, 951-962

Barnett, W. \& Ganz, S. C. (2018). Corruption, Organizational Failure, and Industrial Regeneration. Working Paper. https://spp.gatech.edu/publications/pubFile/5502

Barthwal, R. R. (2004). Industrial Economics: An introductory textbook. 2nd edition. New Dehli: New Age International Publishers

Baumol, W. J. (1990). Entrepreneurship: Productive, Unproductive, and Destructive. Journal of Political Economy 98(5, Part 1):893-921.

Ben-Zvi, S. (1981). Determining Industrial Comparative Advantages in Areas of Proposed Water Navigation Projects: An Industrial Location Analysis. Contract Report 81-006 December 1981. U.S. Army Corps of Engineers Water Resources Support Center Institute for Water Resources.

Beji S. \& Belhadj, A. (2016). The Determinants Of Industrialization: Empirical Evidence For Africa. European Scientific Journal April 2016 /SPECIAL/ edition

Chang, H. J. (2009). Industrial Policy: Can We Go Beyond an Unproductive Confrontation? A Plenary Paper for ABCDE (Annual World Bank Conference on Development Economics). Seoul, South Korea 22-24 June 2009

Chen, L. C. (2007). An Analysis on the Local Characteristic Industry in Taiwan. J. Chin. Trend Forw. 3, 81-98.

Clague, C. Keefer, P., Knack, S. \& Olson, M. (1997) 'Institutions and Economic Performance: Property Rights and Contract Enforcement' in Clague, C. (ed) Institutions and Economic Development, John Hopkins, Baltimore.

Coelli, T.J.; Prasada Rao, D.S.; O’Donnell, C.J.; Battese, G.E (1998). Introduction Efficiency Productivity Analysis; Kluwer Academic Publishers: Dordrecht, The Netherlands.

Corley, T. A. B. (1990). Emergence of the theory of industrial organization, 1890-1990. Business \& Economic History, 19, 83-92.

Curry, B. \& George, K. D., (1983). Industrial Concentration: A Survey. The Journal of Industrial Economics, 31, pp. 203-255.

Drucker, P. F. (1985) “The Practice of Innovation”, Innovation and Entrepreneurship Practice and Principles, Harper \& Row, New York, pp. 19-33

Drucker, P. F. (1999) "Management's New Paradigms", Management Challenges for the 21st Century, Harper Business, New York, pp. 1-41.

Drucker, P. (2004). Management Challenges of the 21st Century

Evans, P. B., (1995). Embedded Autonomy: States and Industrial Transformation, Princeton, NJ: Princeton University Press.

Fan, S.M.; Chou, T.L (2008). Local Development Strategies in Taiwan: Governance and Networking. J. City Plan. $35,99-122$

Friedrich Ebert Stiftung, (2004). FES Trade Union Country Reports: The Case of Ghana. A Background Paper Prepared For Friedrich Ebert Stiftung, February 2004.

Hafner, Marco et al. 2016. The Cost of Non-Europe in the Area of Organized Crime and Corruption. Brussels, Belgium: RAND Europe.

Hartley, Michael C. Mr., "Marcuse on The Two Dimensions of Advanced Industrial Society and The Significance of His Thought Today" (2011).Senior Honors Projects. Paper 230. http://digitalcommons.uri.edu/srhonorsprog/230http://digitalcommons.uri.edu/srhonorsprog/230

Huang, C.J. (1998). Industry Planning of Organic Agriculture of Taiwan. Chin. J. Agribus. Manag. 4, $102-126$. 
Hottenrott H. \& Thorwarth, S. (2011). Industry Funding of University Research and Scientific Productivity. KYKLOS, Vol. 64 - November 2011 - No. 4, 534-555.

Liau, S. J. \& Chou, T. L. (2000). The Primary Study of Local Development Institution Form in Taiwan: The Discussion of Some Northern Coastal Areas. J. Archit. Plan. 1, 13-34

Leiper, N., Stear, L., Hing, N., \& Firth, T. (2008). Partial Industrialization in Tourism: new model. Current Issues in Tourism, 11(3), 207. http://dx.doi.org/10.2167/cit356.0.

Killick, T. (2010). Development Economics in Action: A Study of Economic Policies in Ghana, 2nd edn. New York, NY and Abingdon: Routledge.

Khan, M. H. (2014). The Industrial Policy Governance Challenge. A Presentation. SOAS, University of London. German Development Institute, Bonn 15th September 2014

Klapper, Leora, Amit, R. and Guillen. M. F. (2010). Entrepreneurship and Firm Formation Across Countries. Pp. 129-158 in Lerner, J. and Schoar, A. (eds.). International Differences in Entrepreneurship. Chicago: University of Chicago Press.

McGee, J. S., (1975). Efficiency and Economies of Scale in Goldschmid, H.; Mann, H. M. and Weston, J. F. (eds.), Industrial Concentration: The New Learning (Little, Brown, Boston, Massachusetts, U.S.A.)

Midelfart-Knarvik, K. H., Overman, H. G., Redding, S. J. \& Venables, A. J. (2000). The Location of European Industry. Report prepared for the Directorate General for Economic and Financial Affairs, European Commission.

Ministry of Trade and Industry. (2015). Ghana Industrial Policy. https://new-ndpcstatic1.s3 .amazonaws.com/CACHES/PUBLICATIONS/2016/04/16/Ghana+Industrial+Policy.pd

Mohamed, Z., Shamsudin, M. N., Latif, I. A., \& Mu'azu, A. U. (2013). Measuring competition along the supply chain of the Malaysian poultry industry. International Conference on Social Science Research, 4-5 June 2013, Penang, Malaysia.

Murphy, Kevin M., Shleifer, A. and Vishny, R. W. (1993). Why Is Rent-Seeking So Costly to Growth?

The American Economic Review 83(2):409-14.

Ng, F. \& Yeats, A. (1999) 'Good Governance and Trade Policy: Are They the Keys to Africa's Global Integration and Growth?’ Policy Research Working Papers World Bank, January.

Nyanteng, V. K. (1993). Policies and Options of Ghanaian Economic Development. Accra: University of Ghana, Legon.

OECD (2014). Report. Better Policies for Development 2014: Policy Coherence and Illicit Financial Flows, OECD Publishing. doi: http://dx.doi.org/10.1787/9789264210325-en

Okuno-Fujiwara M., (n. d.). Industrial Policy in Japan: A Political Economy View, Masahiro Okuno-Fujiwara Chapter http://www.nber.org/chapters/c8667.pdf

Otalu J. A \& Keji Anderu, S. (2015). An Assessment of the Determinants of Industrial Sector Growth in Nigeria. Quest Journals Journal of Research in Business and Management Volume 3 Issue 7(2015) pp: 01-09

Owoo N. S. and Page J. (2017). Industrial Policy in Ghana: From a Dominant State to Resource Abundance The Economy of Ghana Sixty Years after Independence (2017). Eds Ernest Aryeetey and Ravi Kanbur. Oxford University Press. 116-191

Pan, Y. C., \& Chiu, Y. H. (2017). Formulating Assessment Indices and Strategies for the Transition to Local Industrial Development in Taoyuan City, Taiwan. Sustainability, 9(3), 364.

Patton M. Q. (2005) Qualitative research. John Wiley \& Sons, Ltd.

Pepall, L., Richards, D. \& Norman, G. (2008). Industrial Organization: Contemporary Theory and Empirical Applications, 4th edition (Blackwell Publishing, Oxford, England).

Porter P. K., Scully G. W., and Slottje D. J., (1986). Industrial Policy and the Nature of the Firm. Journal of Institutional and Theoretical Economics 142 (1986), 79-100 Zeitschrift für die gesamte Staatswissenschaft.

Porter, E. M. (1990). The Competitive Advantage of Nations. Harvard Business review. March-April, 1990.

Pritchett, L. (2001). Where has all the education gone? World Bank Economic Review, 15(3), pp. 367-391.

Raible, M. (2013). Industrial Organization theory and its contribution to decision-making in purchasing. 2nd IBA Bachelor Thesis Conference, November 7th, 2013, Enschede, The Netherlands. 
https://essay.utwente.nl/64302/1/Max\%20Raible.pdf

Ramsey, J. (2001). The Resource Based Perspective, Rents, and Purchasing's Contribution to Sustainable Competitive Advantage. Journal of Supply Chain Management. 37(3), pp. 38-47.

Rodrik, D. (2008). Normalizing Industrial Policy. Working Paper NO. 3. Commission on Growth and Development. The International Bank for Reconstruction and Development/The World Bank.

Rodrik, D. (2008), The Real Exchange Rate and Economic Growth. Brookings Papers on Economic Activity, Fall 2008, pp. 365-412.

Rose-Ackerman, S. \& Palifka. B. J. (2016). Corruption and Government: Causes, Consequences, and Reform. New York: Cambridge University Press.

Quartey, P. (2006). 'The Textile and Clothing Industry in Ghana', in H. Jauch and R. Traub-Merz (eds) The Future of the Textile and Clothing Industry in sub Saharan Africa. Bonn: Bub Bonner Universitats-Buckdruckerei, 135 46.

Sharma, R. K. (2014). Industrial Development of India in Pre and Post Reform Period. Journal of Humanities And Social Science (IOSR-JHSS) Volume 19, Issue 10, Ver. IV (Oct. 2014), PP 01-07

Scherer, F. M., (1970). Industrial Market Structure and Economic Performance. Rand McNally, Chicago, Illinois: U.S.A.

Shepherd, W. G., \& Wilcox, C. (1979). Public policies toward business. 6th edition. Richard D. Irwin, Inc.

Shuai, J. (2014). Industrial Organization: Theory and Application (2014). http://www.cblinternational.com/docs/csu0614/io-theory-application.pdf

Sachs, J. and Warner, A. (1995) 'Economic Reform and the Process of Global Integration' Brookings Papers on Economic Activity, No. 1.

Steel, W. F. (1972). 'Import Substitution and Excess Capacity in Ghana'. Oxford Economic Papers 24(2): $212-40$. Stevenson, R. W. (1997). The Velvet Fist of Fannie Mae. The New York Times, April 20.

The Board of the Netherlands Court of Audit (2012). Dare to measure: Evaluation designs for industrial policy in The Netherlands. Final report of the Impact Evaluation Expert Working Group, November

The Economic Commission for Africa (2014). Dynamic Industrial Policy in Africa: Innovative Institutions, Effective Processes and Flexible Mechanisms. United Nation Economic Commission for Africa and African Union.

The Royal Netherlands Economic Association (KVS, 2004), Innovatie in Nederland: De markt faalt en de overheid draalt (Innovation in the Netherlands: The market fails and the government dallies), editors Bas Jacobs and Jules Theeuwes

Tirole, J. (1988). The Theory of Industrial Organization. The MIT Press.

UNIDO (2013). The industrial Policy Process in Ghana. Development Policy, Statistics and Research Branch Working Paper 2/2013

Tsu-tan Fu, et. al (2014). Industrial policy, Structural Change, and Pattern of Industrial Productivity Growth in Taiwan. This paper is prepared for the third World KLEMS Conference, Tokyo, Japan on May 19, 2014. Available at: http://www.worldklems.net/conferences/worldklems2014/worldklems2014 Lin.pdf.

Tung, G.-S., Lin, C.-Y., \& Wang, C.-Y. (2010). The market structure, conduct and performance paradigm reapplied to the international tourist hotel industry. African Journal of Business Management, 4(6), 11161125.

Victor, P. \& Franckeiss, A. (2002). The five dimensions of change: an integrated approach to strategic organizational change management. Strategic Change. Strat. Change 11: 35-42 (2002) https://onlinelibrary.wiley.com/doi/pdf/10.1002/jsc.567. DOI: 10.1002/jsc.567

Wirth, M. O. \& Bloch, H. (1995). Industrial Organization Theory and Media Industry Analysis, Journal of Media Economics, 8:2, 15-26, DOI: 10.1207/s15327736me0802_3

Weil, D. N. (2013) 'Economic Growth’ (3rd Ed.), Prentice Hall.

World Bank (WB) (1985). 'Ghana: Industrial Policy, Performance and Recovery'. West Africa Region and Industry Department of the World Bank, Report 5716GH. Washington, DC: World Bank. Available at http://documents.worldbank.org/curated/en/832361468032174119/Ghana-Industrial-policy-performance-andrecovery 


World Bank (2019). World Development Indicators. Available at
https://data.worldbank.org/indicator/NY.GDP.MKTP.KD.ZG?locations=GH

Yu, C. L.; Lu, D. B. \& Luo, M. S. (2010). The Study of Local Charm Industries Design Process: A Case Study of Baihe Lotus Industry. J. Archit. 72, 129-146.

Zakari, A., (2013). The industrial policy process in Ghana. Development Policy, Statistics and Research Branch Working Paper 2/2013. United Nations Industrial Development Organization (Unido), Vienna.

Zelleke, G., Sraiheen, A. \& Gupta, K. (2013) 'Human Capital, Productivity and Economic Growth in 31 SubSaharan African Countries for the Period 1975-2008' International Journal of Economics and Finance; Vol. 5, No. 10.

(1992), "Industry", Pigment \& Resin Technology, Vol. 21 Iss 11 pp. 23 - 24, http://dx.doi.org/10.1108/eb042995) 